\title{
Low achievers and the quest for institutional standard in mathematics education: A phenomenology of subject matter experts' opinions from Nigerian higher education
}

\author{
Joshua Abah ABAH* \\ Federal University of Agriculture Makurdi, Benue State, Nigeria
}

\begin{tabular}{|c|c|}
\hline & \\
\hline $\begin{array}{l}\text { Original Article } \\
\text { doi: } 10.18860 / \text { ijtlm.v1i2.6338 }\end{array}$ & $\begin{array}{l}\text { This study adopts a phenomenological paradigm to present } \\
\text { mathematics experts' opinions on the existence of low achievers in }\end{array}$ \\
\hline $\begin{array}{l}\text { Keywords: } \\
\text { mathematics education, low } \\
\text { achievers, phenomenology, } \\
\text { grading system, academic } \\
\text { achievement }\end{array}$ & $\begin{array}{l}\text { Nigeria's higher education system. Six career mathematicians } \\
\text { volunteered from among the participants at a conference of one of } \\
\text { Nigeria's elite academic group to give their in-depth opinion on the } \\
\text { role of educational institutions in handling low achievers, their } \\
\text { impact on Nigeria's quest for quality education, and personal } \\
\text { approaches for managing low achievers in the mathematics } \\
\text { classroom. The explication of the responses of the mathematics } \\
\text { experts indicates concerns about the admission system of higher } \\
\text { educational institutions and some pertinent pedagogical } \\
\text { inadequacies of pure mathematicians. The study also revealed that } \\
\text { the continual existence of low achievers in the discipline } \\
\text { encourages high rate of dropping-out, poor quality of mathematics } \\
\text { educators, and examination malpractice. Participants suggest } \\
\text { counseling intervention, retraining of mathematics lecturers in } \\
\text { teaching methodologies, and special mindset-boosting programmes } \\
\text { as ways of handling low achievers in mathematics education. The } \\
\text { phenomenology also unveiled certain unintended outcomes that } \\
\text { may form the basis for future research into the peculiar attitudinal } \\
\text { characteristics of academic mathematicians. }\end{array}$ \\
\hline
\end{tabular}

(C) 2018 IJTLM. All rights reserved.

*Corresponding author.
E-mail: abahjoshua.a@gmail.com

How to cite: Abah, J. A. (2018). Low achievers and the quest for institutional standard in mathematics education: A phenomenology of subject matter experts' opinions from Nigerian higher education. International Journal on Teaching and Learning Mathematics, 1(2), 51-65.

\section{INTRODUCTION}

Mathematics education is a field of study concerned with the tools, methods and approaches that facilitate the practice of teaching and learning mathematics. Mathematics education, particularly at the higher education level, prepares students for quantitative and symbolic reasoning and advanced mathematical skills through general education, services, major and graduate programmes (Odili, 2012). The mathematics educator is concerned with curriculum development, instructional development and the pedagogy of mathematics. Iji, Abah and Anyor (2017) pointed out that mathematics education basically prepares students to become innovative mathematics instructors, professionally prepared to communicate mathematics to learners at all levels. 
Mathematics educators see mathematics not simply as a body of knowledge or an academic discipline but also as a field of practice. According to Kilpatrick (2008), this is because they are concerned with how mathematics is learned, understood and used; as well as what it is, they take a comprehensive view. Mathematics education looks beyond applications to ways in which people think about mathematics, how they use it in their daily lives, and how learners can be brought to connect the mathematics they see in school with the mathematics in the world around them (Iji, Abah \& Anyor, 2018).

In Nigeria, the National Universities Commission (NUC) has approved and accredited mathematics education programmes in over fifty (50) universities (National Universities Commission, 2012). Within these programmes, students are exposed to the realities of the modern classrooms they are expected to direct. With respect to the Benchmark Minimum Academic Standard (BMAS) for mathematics education, the National Universities Commission - NUC (2007) reiterated the broad objectives of mathematics education as: (1) the acquisition, development and inculcation of the proper value orientation for the survival of the individual and the society; (2) the development of the intellectual capacities of individuals to understand and appreciate their environments; (3) the acquisition of both physical and intellectual skills which will enable individuals to develop into useful members of the community; (4) the acquisition of an objective view of local and external environments; (5) the development of the spirit of enquiry, creativity and entrepreneurship in mathematics teachers; and (6) the enhancement of the skills of mathematics teachers in the use of new technologies.

The significance of academic and social excellence in mathematics education is highlighted in the emphasis on intellectual capacities and skills expected to be displayed by students of the noble discipline. Academic achievement represents performance outcomes that indicate the extent to which a person has accomplished specific goals in instructional environments such as school, college and university (Steinmayr, Meibner, Weidinger \& Wirthwein, 2015). Academic performance is reflected not only in a person's grades at school but also manifested in the individual's intelligence, participation in extracurricular activities, initiative in leadership, and sustainable skills (Williams, n.d.). Academic success entails the overall well-being of an individual with respect to prescribed tasks.

Within the school setting, assessment of student's performance requires a grading system. Omotosho (2013a) asserts that a grading system is a platform for the application of assessment instruments. Many universities world over have adopted the Cumulative Grade Point Average (CGPA) grading system to evaluate student's performance. A very in-depth study of CGPA has shown that it is the best tool for describing students' performance in a single numeral (Omotosho, 2013a). The CGPA also provides an easy approach to classifying student's overall academic attainment. Beginning form the 2015/2016 academic session across Nigeria, a uniform 4-point grading system was adopted for universities within the country. This system was later suspended by the NUC in the 2017/2018 academic session and replaced with the previous 5-point grading system.

The CGPA system is fed by a corresponding course system that attaches credit units to courses in line with a nationwide BMAS recommendation. Table 1 summarizes a typical computation sequence of the CGPA (For extensive consideration, see Omotosho (2013a; 2013b) and Barnes (2005)). 
International Journal on Teaching and Learning Mathematics

2018, Vol. 1, No. 2, pp. 51-65

P-ISSN: 2621-2188, E-ISSN: 2621-2196

Table 1. Score and grade point for GPA/CGPA calculation

\begin{tabular}{|c|c|c|c|c|c|}
\hline $\begin{array}{c}\text { (i) } \\
\text { Credit Units }\end{array}$ & $\begin{array}{l}\text { (ii) } \\
\text { Percentage } \\
\text { Scores } \\
\end{array}$ & $\begin{array}{l}\text { (iii) } \\
\text { Letter } \\
\text { Grades }\end{array}$ & $\begin{array}{l}\text { (iv) } \\
\text { Grade Point } \\
\text { (GP) }\end{array}$ & $\begin{array}{l}\text { (v) } \\
\text { Grade Point }\end{array}$ & $\begin{array}{c}\text { Cumulative Grade } \\
\text { Point Average } \\
\text { (CGPA) }\end{array}$ \\
\hline Vary according to & 70 to 100 & $\mathrm{~A}$ & 5 & Derived & Derived \\
\hline contact & 60 to 69 & B & 4 & multiplying & multiplying (i) and \\
\hline assigned to each & 50 to 59 & $\mathrm{C}$ & 3 & and (iv) and & (iv) and dividing by \\
\hline course per week & 45 to 49 & $\mathrm{D}$ & 2 & dividing by total & total credit units for \\
\hline per semester and & 40 to 44 & $\mathrm{E}$ & 1 & credit units & courses registered till \\
\hline $\begin{array}{l}\text { according to } \\
\text { student workload }\end{array}$ & 0 to 39 & $\mathrm{~F}$ & 0 & & date \\
\hline
\end{tabular}

The course system translates to five (5) classes of degree based on CGPA. This classification is shown in Table 2.

Table 2. Degree classification based on CGPA

\begin{tabular}{cc}
\hline Cumulative Grade Point Average (CGPA) & Class of Degree \\
\hline $4.50-5.00$ & First Class \\
$3.50-4.49$ & Second Class Upper \\
$2.40-3.39$ & Second Class Lower \\
$1.50-2.39$ & Third Class \\
$1.00-1.49$ & Pass \\
$<1.0$ & Fail \\
\hline
\end{tabular}

In line with long established standards, academic performance below a CGPA of 2.0 is considered poor. The Technical Education Quality Improvement Programme (TEQIP) Phase II (2012) classified weak students as those who had a Third Class, had failed more than 40 or 50 percent of their courses in a given year. Such students lack self-confidence and perhaps do not communicate, do not seek help and have difficulty adjusting to the school environment. Researches have shown severally that there is a clear statistical relation between selfconfidence, defined in this connection as a positive self-concept and high self-efficacy, and average achievement scores in Mathematics (Haahr, Nielsen, Hansen \& Jakobsen, 2005).

Many terms and descriptions are used in referring to learners in the bottom category of academic performance. Barnes (2005) lists "remedial", "disadvantaged", "special needs", "under-achievers", "slow-learners", "low achievers", and "low attainers", as a range of terms for describing this category of students. In any of the widely-used terms, low achievers are learners who do not meet the required standard of observable mathematics performance as set out by the school (Barnes, 2005). They exist wherever classification of academic achievement exists and the term, particularly in mathematics education, does not indicate any form of labeling or derogatory connotations.

The ultimate aim of undertaking any important life endeavour is to achieve success. To achieve the aims and objectives of mathematics education, students must strive to attain appreciable academic standard in the display of their ability. Williams (n.d.) asserts that the ability to master diverse sets of skills illustrates intelligence, curiosity and persistence, qualities attractive to universities and employers. Von Stumm, Hell and Charmorro-Premuzic (2011) report that much psychological research has focused on identifying predictors of academic performance, with intelligence and effort emerging as core determinants.

In clarifying the ambiguity associated with the definition of academic success, Barnes (2005) attempted a revised definition and model. In Barnes' framework, academic success is defined as 
inclusive of academic achievement, attainment of learning objectives, acquisition of desired skills and competencies, satisfaction persistence, and post-school performance. In a very real sense, academic achievement is a threshold assessment - it captures a student's ability to meet performance criteria. Barnes (2005) maintained that in this way, grades are intended to measure learning or knowledge; in other words, they are proxy measurements intended to capture attainment of learning objectives and acquisition of skills and competencies. Persistence is vital to the model of academic success because it captures the focus, drive, and forward progression needed by students to complete a programme of study such as mathematics education (Abah, Awen \& Kuse, 2018). Academic success is expected to manifest beyond the school setting in the form of career success (Abah, Age \& Agada, 2019).

The low achiever consistently fall short of all performance criteria. An explanation sometimes given by faculty and even students for weak performance was distraction, that is, some students lacked discipline, fell into bad habits, or viewed schooling mainly as a time to have fun. (TEQIP Phase II, 2012). Among these were possibly some students who, by their own admission, were disinterested in their studies. The TEQIP report acknowledges that it is significant that the factors that produce weak students even among those who enter higher education with good marks are more psycho-social in nature than socio-economic. Schoolspecific factors identified as responsible for low achievement include: (1) poor teaching either because of poor domain knowledge, or poor pedagogy including a lack of interaction and creativity in the classroom; (2) improper sequencing or unevenness of curricular or syllabi and related issues; (3) inadequate exposure of students to real world situations before graduation; and (4) inadequacy of discussion on performance, counseling and mentoring (TEQIP Phase II, 2012).

School level factors are expected to influence classroom level factors. Low achievers are definitely affected by factors at the school level which are related to the same key concepts of quantity of teaching, provision of learning opportunities, and quality of teaching (Cremers \& Kyriakides,2010). The element of school climate is an important predictor for low achievers since learning is the key function of a school. Positive student-related school climate may be precondition to good outcomes (Haahr et al, 2005). Other scholars place responsibility for school failure on a variety of factors including student cognitive abilities, communication style, home environment, and the socializing and academic influences of the school and society (Schneider \& Lee, 1990; and Naakaa, Abah, \& Atondo, 2019). At the motivational level, Reiss (2009) identified six key reasons for low achievement namely, fear of failure, incuriosity, lack of ambition, spontaneity, lack of responsibility, and combativeness. More research mentions student's effort - the amount of time and energy that students expend in meeting the formal academic requirements established by the school - as fundamental to understanding how unequal outcomes emerge from structural factors within the school that are imposed on students and choices that students make on being placed in such structures (Abah, 2018; Carbonaro, 2005; and Abah, Age \& Agada, 2019).

Wilson, Damiani and Shelton (2002) provided an extensive review of theoretical foundations of attribution research. The premise of attribution therapy holds that rather than targeting people's behavior or anxiety, it is better to change their attributions from a pejorative to nonpejorative ones. Wilson, Damiani and Shelton (2002) emphasized that doing so might succeed in breaking the exacerbation cycle, making people to avoid the self-blame that follows from a pejorative attribution, thereby avoiding further increases in anxiety, poor performance, and subsequent self-blame. Therefore, to provide adequate support and remediation for low 
achievers, Barnes (2005) identified five aspects to be focused on in the instructional approach of the intervention: (1) more focus on relational and conceptual understanding as opposed to learning by rote and memorization; (2) creating meaningful learning contexts that actively involve learners; (3) greater emphasis on problem solving and less emphasis on computation and arithmetic skills; (4) the importance of social interaction in the learning process (i.e. group work, reciprocal teaching, games, etc.); and (5) the importance of language development and discussion with and between learners in teaching mathematics.

On the basis of the theoretical explanations of low achievement considered so far in this review, some selected empirical works are notable in establishing existing connections and explaining trends in academic achievements. Sriram (2014) compared groups of high-risk firstyear students at a large private university in southwestern United States on mindset and on the dependent variables of academic effort and academic achievement. A 3-item Implicit Theory of Intelligence Scale based on the work of Dweck and colleagues were used to measure the student's mindset. The three items in this measure are: (a) you have a certain amount of intelligence and you really can't do much to change it; (b) your intelligence is something about you that you can't change very much; and (c) you can learn new things, but you can't really change your basic intelligence. The Student Readiness Inventory (SRI) was used to capture unique aspects of academic effort including academic discipline, academic self-confidence, commitment to college, general determination, goal striving, and study skills. Academic achievement was operationalize as students' first-year CPGA obtained from the university records. Analysis of the results of the study confirmed the stability of mindset as a construct, and affirmed that growth mindset did lead to increased academic effort in the college student. Also, the change in academic effort from the four-week mindset intervention did not make a statistically significant difference in grades between the two groups.

Similarly, Devers (2015) embarked on a study to determine if student performance in an advanced physics classroom could be improved by emphasizing that students' abilities are malleable rather than fixed. Students participated in a lecture, in which they learned about brain function and how intelligence physically manifests, read a supporting article, and discussed the implications. Following the intervention, students had a slight, not significant, increase in growth mindset and academic performance. There was a positive correlation between adoption of a growth mindset and academic performance for the high school students but negative for college participants due to some extenuating circumstances.

Hotulainen, Mononen and Aunio (2016) report the results of the Improving Thinking Skills (ITS-I) Intervention study on the thinking skills of low achieving first graders. The intervention lessons (12 lessons each lasting for 45 minutes) offer enriched-discovery learning activities and tasks to be solved through inductive reasoning. Analysis of results from a sample of 149 first graders showed that in the beginning of the study, there were differences in thinking skills, mathematical skills, listening comprehension skills and reading fluency between the lowachieving and well-performing groups but the low-achieving group was able to reach the level of their well-performing peers at the end of the intervention in all measures.

In the same vein Maqsad (2006) conducted a study to examine the effects of metacognitive instruction on mathematics achievement and attitude towards mathematics of low mathematics achievers at a middle school in Northwest Province of South Africa. Forty (40) standard 7 pupils were identified whose non-verbal general ability and previous mathematics achievement were significantly lower than those of other standard 7 pupils. These subjects were randomly assigned to an experimental and a control group. Metacognitive strategies in solving 
mathematical problems related to four mathematical topics were individually taught to members of the experimental group, while the pupils in the control group were taught the four mathematics topics conventionally. The comparisons of pretest and posttest measures of general ability, metacognitive awareness, attitude towards mathematics, and mathematics achievement revealed that the posttest scores of all the four variables for the experimental group were significantly higher than those for the control group.

The few empirical studies considered here have stressed the importance of right mindsets, individual efforts and special interventions in the education of low achievers. The first two studies (Sriram, 2014; and Devers, 2015), in particular, have revealed that academic success requires more than ability. It requires the application of ability and the growth of ability through sustained hard work, and academic tenacity - mindsets, goals, and self-regulatory skills, even on the part of low performing mathematics education student (Dweck, Waton \& Cohen, 2014). In the light of these studies, this present work attempt to go a step further into the professional context of low achievement in mathematics education in Nigerian higher education. The approach of this current effort is phenomenological and it seeks to document the opinion of the subject matter experts on the existence of this category of students in the face of the quest for quality education in Nigeria.

It is not surprising that there are low achievers in mathematics education at the university level in Nigeria. The categorization of academic performance is more glaring within the university system where exiting CGPAs are considered vital determinants of employability in a shrinking job market. Also, low academic performance most of the time is a pointer to certain underlying characteristics of the individual which may likely show sooner or later in activities within the larger society. It is against this background that this study takes a phenomenological stance to investigate the complexity of issues surrounding the existence of low achievers in mathematics education. In sharply deviating from the approaches of mainstream research in this area, this study takes the problem to mathematics subject matter experts and highlights their professional thoughts about students struggling with grades in mathematics.

Specifically, the following questions guided this study: (1) what are mathematics experts' opinions of the role of educational institutions in handling low achievers? (2) what are mathematics experts' explanations of the impact of low achievers on Nigeria's quest for quality education? (3) what are mathematics experts' personal approaches to managing low achievers in the mathematics classroom?

\section{METHOD}

This study adopts phenomenology as a research a paradigm. Phenomenological research generally agrees that the central concern is to return to embodied, experiential meanings, by aiming for fresh, complex, rich descriptions of a phenomenon as it is concretely lived (Finlay, 2009). Phenomenological research methods are responsive to both the phenomenon and the subjective interconnection between the researcher and the researched. Laverty (2003) explained that the "life world" is understood as what we experience pre-reflectively, without resorting to categorization or conceptualization, and quite often includes what is taken for granted or those things that are common sense. The study of these phenomena intends to return and re-examine these taken-for-granted experiences and perhaps uncover new or forgotten meanings.

A detailed trace of the historical roots of phenomenology is given by Abakpa, Agbo-Egwu and Abah (2017). The original method introduced by Husserl involves three steps: (1) one assumes the transcendental phenomenological attitude, (2) one brings to consciousness an 
instance of the phenomenon to be explored, whether actual or fictional, and with the help of free imaginative variation, one intuits the essence of the phenomenon being investigated, and (3) one carefully describes the essence that has been discovered (Giorgi, 2007). But over the years, some modifications and simplifications have been made in attempts to adapt phenomenology to empirical research situations. One of the most popular adaptation, provided by Giorgi (2007), include: (1) the descriptions to be analyzed are obtained from others, who remain within the natural attitude, but the researcher does assume the phenomenological reduction, (2) one tries to determine the psychological essence of the phenomenon rather than its philosophical essence or, the psychological perspective is adopted first and then the essence, or the most invariant meaning structure for a specific context, is determined with respect to that perspective, (3) the imaginative variations that are employed are done in dialogue with the empirical variations that are given in the descriptive data, and (4) the eidetic structure that is discovered and described is considered to be typical rather than universal. In simpler terms, the steps are: (1) assume the phenomenological attitude, (2) read entire written account for a sense of the whole, (3)delineate meaning units, (3) transformed the meaning units into sensitive statements of their lived meanings, and (4) synthesize a general structure of the experience base on the constituents of the experiences (Broomé, 2011, p.2)

Unlike the prescribed methodology of the positive sciences, phenomenology does not follow prescribed rules (McPhail, 1995). Rather, it has a set of guiding principles that researcher must keep in mind as they proceed. According to Broomé (2011), it is the first person psychological perspective that is sought so that an emphatic position can be adopted by the end-user of the research. For this present study, the phenomenon of interest is the existence of low achievers in mathematics education, particularly within the Nigerian higher education system.

The participants of this study are mathematics subject matter experts who teach mathematics in higher educational institutions in Nigeria. The study concentrated on these mathematicians after considering the fact that more than fifty percent (50\%) of the curricular content of the mathematics education programme across Nigerian tertiary institutions are normally handled by these non-educationist professionals (NUC, 2007). Likewise, observations from students' complaints and examination records-based studies indicate that many mathematics education students face more difficulties in the core computational courses of the programme (Abah, 2018). Specifically, six (6) subject matter experts provided written responses to an interviewstyled open-ended questionnaire tagged “Are we stuck with low achievers?" They were randomly drawn from the participants of an annual conference of Nigerian mathematicians held in Makurdi, Benue State, in May, 2017. The six (6) mathematicians voluntarily accepted the interaction with the researcher and were duly informed about the study.

The heading "data analysis" is often deliberately avoided in phenomenological methodology section considering its dangerous connotations for phenomenology. In clarifying this, Groenewald (2004) maintains that the term "analysis" usually means a "breaking into parts" and therefore often means a loss of the whole phenomenon, whereas the preferred term, "explication", implies an investigation of the constituents of a phenomenon while keeping the context of the whole. Explication of the data for this study has five steps or phases (in line with the simplifications provided by Groenewald 2004), namely, bracketing and phenomenological reduction; delineating of units of meaning; clustering of units of meaning to form themes; summarizing each interview, validating it and where necessary modifying it; and extracting general and unique themes from all the interviews and making a composite summary. 
To abstain from the use of personal knowledge is what phenomenologists called "bracketing", which is a setting aside of what we already know about a given phenomenon (Bevan, 2014). In an attempt to overcome the uncritical dogmatism of the natural attitude, what bracketing (abstention) amounts to is a dialogue with the self, to become reflexive when asking questions. Bracketing is a method used in qualitative research to mitigate the potentially deleterious effects of preconceptions that may taint the research process (Tufford \& Newman, 2010). To achieve an effective bracketing for this study, reflective journaling was use to sustain a reflexive stance throughout the research process while interview questions were posed with self-consciousness of the researcher's own natural attitude to avoid asking theory-laden questions (Aspers, 2004; Tufford \& Newman, 2010; Bevan, 2014).

To protect the privacy of the participants of this study, the interview instrument was devoid of personal details. The experts' opinions on the issue of interest are presented in a coded form with the term math expert-1 referring uniquely to the first respondent, math expert- 2 for the second respondent, and so on.

\section{RESULTS AND DISCUSSION}

\subsection{The Role of Educational Institutions in Handling Low Achievers}

In responding to an interview question framed to elicit mathematics experts' opinions on how best higher educational institutional can manage the existence of low achievers in mathematics, respondents seem to toe the line of preventive control instead of head-on management. In this regard, Math Expert-3 has this to say:

In my view, higher educational institutions should be strict when admitting new students to mathematics programmes. Interview should be conducted in addition to the post-UTME screening.

By post-UTME, Math Expert-3 was referring to the aptitude test admission seekers take after the nationwide Unified Tertiary Matriculation Examinations. Post UTME screening are adopted by a wide range of monotechnics, polytechnics, colleges of education and universities to select only proficient candidates from among secondary school leavers who passed the UTME conducted by the Joint Admissions and Matriculation Board (JAMB). The opinion of Math Expert-3 suggests that the sense of mistrust that brought about the introduction of Post UTME screening in the first place is beginning to affect the Post-UTME itself. Agreeing with Math Expert-3, Math Expert-4 suggested "best students in WAEC or Senior Secondary School should be encouraged to study mathematics and mathematics education," WAEC being the common term for the Senior School Certificate Examination (SSCE) organized by the regional West African Examination Council.

Similarly, Math Expert-6 put it thus:

In my opinion, students should be admitted into the mathematics programme base on their demand to study mathematics.

Math-Expert-6 unveils an underlying problem in Nigeria's higher education admission system. Abah, (2017) mentioned the practice of imposition of programmes of study by higher educational institutions, with many students ending up studying disciplines they never dreamt of. Evidently, many mathematics education students undoubtedly come in from basic and secondary schools where, historically, mathematics teaching does not always allow students to develop favourable disposition towards the subject. By giving admission to candidates "base on their demand to study mathematics", higher educational institutions in the country will by placing round pegs in round holes in terms of students' preparedness and mindset for mathematics education. 
Another theme that emerged from the delineating and clustering of units of meaning in this study is the need for improvement in pedagogy. Math Expert-5 suggests "teachers (of mathematics) in higher institutions should use learner-centred techniques of teaching such as constructivist models or scaffolding methods". In the same vein, Math Expert-2 has this to say:

Teachers [of mathematics] should see everybody as their students, both the high flyers and below average students. Mathematics should be simplified and more applications should be incorporated.

The implication of this line of thought is that many pure mathematicians teaching mathematics education students do not have the patience to handle low achievers and may be openly discriminating against them (Abah, 2017). To buttress this point, Math Expert-1 gives this elaboration:

Firstly, the problems boil down to the subject handlers. By that, I mean the lecturers themselves. How much do the lecturers understand the subject itself? Mathematics on its own is a difficult and challenging area, and the lecturers are not helping matters. Some know the subject but can't teach it. Others can teach but certainly do not understand the subject best enough to teach. So my submission is, sound lecturers are to be engaged in teaching a particular area in this subject and these lecturers should be allowed to go out for training.

The place of mastery of subject matter in the handling of low achievers cannot be overemphasized. Like Math Expert-1 pointed out, mathematics "lecturers should be allowed to go out for training", particularly to learn how to apply teaching methodologies in the classroom. Such educational training is available via post Graduate Diploma in Education (PGDE) programmes serviced by the National Teachers Institute (NTI) across the country. There are positive tales of school teachers, very senior lecturers and professors of sciences and engineering, who came out of this one-year professional development programme better than they went in (Chukwu et al., 2017; Mayana, 2014). The opinions of the subject matter experts redirect emphasis to the key aspects of school policy which affect learning at both the level of lecturers and students. Creemers and Kyriakides ( 2010) identified these aspects as school policy for teaching (pedagogy) and school policy for creating a learning environment at school.

Introducing an additional theme, Math Expert- 6 added that "the higher institutions of education should create an awareness campaign to help the students". Such efforts may entail emphasis on self-regulation skills and the training in adoption of a growth mindset to academic achievement (Dweck, Walton \& Cohen, 2014). Similar strategy of harnessing students' metacognitive awareness of their malleable abilities featured prominently in the work of Devers (2015) whose intervention consisted of students learning about the brain structure and function, reading an article about the changes the brain goes through while learning followed by a discussion exploring the significance of the material and labels people give each other such as "stupid" and "brainiac". These methods emphasize effort and progress over final outcome, encouraging in-depth learning, creating a growth mindset culture, praising students for their effort not their intellect, differentiating academic tasks, avoiding labeling students and evaluating students based on their growth (Devers, 2015).

\subsection{Impact of Low Achievers on Nigeria's Quest for Quality Education}

When interviewed in line with this research question, respondents pointed out that the continual existence of low achievers in Nigeria's tertiary education system encourages high rate of dropping-out, production of "half-baked" mathematics educators, and examination malpractice. Math Expert-6 presented it this way: 
Their existence will also make students lose hope in coping and understanding the concept of mathematics. Low achievers in our system will collapse the system [eventually] and make students that will be taught by these low achievers to be without any knowledge of the field.

Similar fear for the future of the field was displayed respectively by Math Expert-3 and Math Expert-1.

The number of mathematics graduates without the knowledge (basics) of mathematics is increasing annually. This will create serious downfall in the quest to produce qualitative mathematics teachers and researchers all over Nigeria (Math Expert-3).

They get poor quality and have nothing more than that to offer in the outside world. This waters down the system and it goes round and round to give devastating and poor quality students. Who cannot drive students and, by extension, cannot add to knowledge in the society (Math Expert-1).

According to the Math Experts, the target of mathematics education is lost to this increasing class of low achievers. Mathematics education that is relevant and of quality can develop critical and creative thinking, help learners to understand and participate in public policy discussions, encourage behavioural changes that can put the country on a more sustainable path and stimulate socio-economic development (United Nations Education, Scientific and Cultural Organization - UNESCO, 2012). Mathematics education creates a culture that values continuous learning, problem solving, reflection, and sharing of knowledge. This "knowledge", according to the experts, is presently at grave risk with the proportion of poor performing preservice mathematics teachers existing in the tertiary education system. If, like Math Expert-2 puts it, "people that have no interest to study mathematics ... but just try to cope and read to pass only" will be the ones to act as custodians of the discipline, to provide mathematical understanding that will significantly enhance opportunities and options for shaping the nation's future, then the future, in this sense, is indeed in danger.

In the opinion of Math Expert-5, "the existence of low achievers can encourage (1) rop-outs in schools, or students who are half-baked, (2) examination malpractice". Students in this category tend to be very desperate and implore various means of passing examination with some importing extraneous materials, including smartphones, to the examination hall (Ahmadu, 2016). Most of these students are often caught cheating and are eventually withdrawn from their studies in accordance with the strict regulations of their higher educational institutions. The view point of Math Expert-5 supports Alabi and Abdulkareem (2012) who maintained that the resultant effect of the menace is the gradual loss of confidence in the products of the educational system and the gradual de-recognition of certificates issued by Nigerian schools.

\subsection{Approaches to Managing Low Achievers}

Students, including "weak" ones, appreciate good teaching skills and good domain knowledge among lecturers, but often point to the difficulties they face with lecturers who have less (or outdated) knowledge and those who are not able to impart what they know because of inadequate teaching skill or experience (TEQIP Phase II, 2012). When asked to recount personal approaches towards handling low achievers in their classrooms, the mathematics experts gave a closed set of responses. Math Expert-2 expressed his perspective in the following terms:

We should always come down to their level. We should not be too fast to condemn them. I always encourage and simplify it [Mathematics] for them as well.

In the view of Math Expert-2, low achievers may be slow learners who can catch up if university mathematics teachers apply a little patience in their classrooms. This class of students 
needs more time to understand any problem or to find out the answer, and increase their confidence (Marsh, 2014). Concurring with Math Expert-2, Math Expert-4 added "I give them special attention. I believe we can always bring out the best from any student". Similarly Math Expert-6 thinks "a special consideration should be given to them so that they [can] also understand what is being taught".

Another dimension of responses on personal approaches to managing low achievers points to counseling. Obviously many low achievers were not interested in mathematics (and mathematics education) from the start of their higher educational studies. In this regard, Math Expert-3 suggests "giving the advice to switch to other courses [programmes] that they are sure they will do well [in]". To achieve this, the institutions can appoint active student advisers, mentors or proctors in addition to the conventional counseling services rendered by the guidance and counseling units of the schools (TEQIP Phase II, 2012). According to Bleuer and Walz (2003), parents, teachers and counselors, in dealing with underachievers must first identify the six types of underachievers, namely: (1) Coasters: those who are the ultimate procrastinators, easy-going and unmotivated; (2) Anxious Underachievers: those who want to do better but are too tense and uptight to work effectively; (3) Identity-Searchers: those who are so wrapped up in figuring who they are that they become distracted from school work; (4) Wheeler-Dealers: those who are impulsive, manipulative, and so intent on instant gratification that they see no point in doing well in school; (5) Sad Underachievers: Those who lack the energy needed for school work because of their depression and low self-esteem; and (6) Defiant underachievers: those who underachieve as an act of rebellion.

This identification is necessary because student underachievement is a complex problem that defies a "one size fits all" solution (Bleuer \& Walz, 2003). Just like Math Expert-3 points out, interventions leading to change of course from mathematics education to other programmes must be an informed "advice" in order to avoid what Vogell and Fresques (2017) echoed "concerns that schools artificially boasted test scores by dumping low achievers into alternative programmes". Math Expert-6 maintains "I encourage them to not lose hope, as they can improve themselves".

Relatedly, Math Expert -1 explains thus:

I handle only areas I understand and can apply to any circumstance in the 'outside world' when teaching in the classroom. I motivate the students and always encourage them not to give up, but study hard to make something out of themselves.

\subsection{Unintended Outcomes}

Unintended outcomes are normally effects and consequences which the actors (participants) see as uninteresting but may be very interesting to the researcher (Aspers, 2004). The points referred to in this section are observations, remarks, excuses, and suggestions the participants of the study cannot foresee nor even imagine the full consequences and connection to life-world meaning. In this study, conversations and interactions with the participants yielded two vital unintended consequences.

First, mathematics experts and academics in Nigeria feel issues of consideration for low achievers are only met for secondary and basic education. One of the experts actually responded "nothing" when asked for personal approaches to handling low achievers in the classroom. This points to the lack of educational (teaching methodology) background among the career mathematicians that were the targets of this study. The declination rate when confronted with 
the request to enlist for the study also suggests their general lack of interest in the topic. Many in the target population actually felt concerns for low achievers should never have come up within the higher educational setting, indicating that students struggling with grades "are not serious" and therefore should not be taken seriously.

Second, some of the mathematicians encountered in the course of this study seem to freak out when asked for explanations. This outcome grossly suggest they may not be the type of instructors who give heed to details and pay attention to students' needs, outside the "mechanical" delivery of lecturers in mathematics (Abah, 2017). One of the mathematicians encountered in the course of this research actually suggested the study should have employed a simple questionnaire and that the researcher was in the wrong company - a gathering of mathematicians who generally do not have time for details. Another mentioned that low achievers "delay the understanding [of mathematics] and a lot of time is wasted on them".

The two observable outcomes presented here hold very wide implications for the attitude of non-methodological mathematics teachers in Nigeria's higher education. These observations add to the call for university teachers in the country to take professional courses in teaching methodology. One of the avenues for this professional development programme is already being provided by the National Teachers' Instititute (NTI) which offers the Post-Graduate Diploma in Education (PGDE) meant to fine-tune university teachers' skills in dealing with ever-present classroom challenges. However, very few academics are willing to avail themselves of this opportunity, indicating a kind of "know-it-all" attitude observable among university teachers. Complaints from students mathematics education documented by Abah, Awen and Kuse (2018) and Abah (2017) indicate a negeative spill-over of this attitude in daily instructional delivery. University teachers must first accept that their primary responsibility is to motivate and build students' confidence which in turn encourage the learners in understanding the instructional content of the curriculum being delivered. As Anyagh, Honmane and Abah (2018) observes, the attitude of teachers, to a large extent, make or mar the students under their tutelage. The challenges presented by low achievement in the university system should bother all stakeholders in the higher education sector and should foster the right attitude in everyone who is interested in national growth and development.

\section{CONCLUSION}

This study has attempted to explore the phenomenon of the existence of low achievers in mathematics-based programmes in Nigeria's higher education system. The issues bothering on the role of educational institutions, effect on quality, and personal approach of teachers of mathematics were deeply considered from the perspective of career mathematicians gathered at a national conference of Nigeria's elite mathematical community. The opinion of these mathematics experts indicate that there is the need to tighten the admissions and screening system of the educational institutions to ensure only adequately proficient candidates are taken in to study mathematics education. There was also the call for improvement in the pedagogy of mathematics to accommodate low achievers. Such improvement will entail professional training of mathematics teachers in the general methodology of teaching. The mathematicians interviewed in this study also suggested counseling interventions to help low achievers improve or change programme of study. The participant of the study raised concerns about the production of "half-baked" graduates of mathematics education who may not correctly pass on the lifeline of mathematical knowledge to future generations in Nigeria. Some of the academics also revealed their personal classroom strategies for motivating low achievers. 
The phenomenological approach adopted in this study unveiled some particular characteristics of non-methodological mathematics that suggests their general attitude towards details. In this respect, future works might consider a comparative analysis of the attitude to teaching and approaches to classroom management of career mathematics and mathematics educationists - the two core categories of professionals involved in the training of mathematics education students.

\section{REFERENCES}

Abah, J. A. (2017). Original higher education experience of graduating students of mathematics education in Nigeria: An autoethnographic approach. Education Journal, 6(6), 177-187.

Abah, J. A. (2018). Academic outcomes in language-dependent and computation-dependent courses among mathematics education students in a Nigerian university: Top-achievers still best of both extremes. Journal of Education \& Social Science (JESS), 6(2), 64-81.

Abah, J. A., Awen, D. A., \& Kuse, N. C. (2018). Correlating university students' academic attainment and sense of hope in science education: A survey from a Nigerian university. International Journal of Education and Knowledge Management (IJEKM), 1(3), 1-17.

Abah, J. A., Age, T. J., \& Agada, G. I. (2019). Determinants of mathematics-related career choice among senior secondary school students in Makurdi metropolis, Benue State, Nigeria. International Journal of Social Sciences, Humanities and Education (IJSSHE), $3(1), 1-16$.

Abakpa, B. O., Agbo-Egwu, A. O., \& Abah, J. A. (2017). Emphasizing phenomenology as a research paradigm for interpreting growth and development in mathematics education. ABACUS: The Journal of the Mathematical Association of Nigeria, 42(1), 391-405.

Ahmadu, F. S. (2016). Examination malpractice in Nigeria's tertiary institutions. Retrieved on $16^{\text {th }}$ May, 2017 from http://authorityngr.com/2016/02/Examination-malpractice-inNigeria-s-tertiary-institutions/

Alabi, A. T., \& Abdulkareem, A. Y. (2012). Managing examination malpractice in Nigerian University system using strategic management policy. Nigerian Journal of Guidance and Counselling, 17(1), 23-29.

Anyagh, P. I., Honmane, O., \& Abah, J. A. (2018). Secondary school students' perception of teachers' attitude towards learning in mathematics in Wukari Metropolis, Taraba State, Nigeria. International Journal of Research and Review, 5(5), 69-75.

Aspers, P. (2004). Empirical phenomenology: An approach for qualitative research. Papers in Social Research Methods, Qualitative Series 9, 1-15.

Barnes, H. (2005). The theory of realistic mathematics education as a theoretical framework for teaching low attainers in mathematics. Pythagoras, 61, 42-57.

Bevan, M. T. (2014). A method of phenomenological interviewing. Qualitative Health Research, 24(1), 136-144.

Bleuer, J. C., \& Walz, G. R. (2003). New perspectives on counselling underachievers. ERIC Digest. Retrieved on $20^{\text {th }}$ May, 2017 from https://www.ericdigests.org/20034/underachievers.html

Broomé, R. E. (2011). Descriptive phenomenological psychological method: An example of a methodology section from a doctoral dissertation. San Francisco, California: Saybrook University.

Carbonaro, W. (2005). Tracking students' effort and academic achievement. Sociology of Education, 78(1), 27-49. 
Chuckwu, E. O., Tarnongu, I. J., Mesuur, F. T., Achukwu, C. E., \& Terkuma, C. (2017). Assessment of the effectiveness of Postgraduate Diploma in Education (PGDE) programme in meeting the job needs of teachers in Gboko, Benue State, Nigeria. International Journal of Education, Culture and Society, 2(2), 69-75.

Creemers, B. P. M., \& Kyriakides, L. (2010). School factors explaining achievement on cognitive and affective outcomes: Establishing the dynamic model of educational effectiveness. Scandinavian Journal of Educational Research, 54(3), 263-294.

Devers, A. (2015). Thinking about intelligence: How student mindsets influence academic performance. Retrieved on $30^{\text {th }}$ April, 2017 from http://www.smcm.edu/mat/wpcontent/uploads/sites/73/2015/06/Allyson-Devers-2015.pdf

Dweck, C. S., Walton, G. M., \& Cohen, G. L. (2014). Academic tenacity: Mindsets and skills that promote long-term learning. Seattle, Washington, DC: Bill \& Mellinda Gates Foundation.

Finlay, L. (2009). Debating phenomenological research methods. Phenomenology \& Practice, $3(1), 6-25$.

Giorgi, A. (2007). Concerning the phenomenological methods of Husserl and Heidegger and their application in psychology. Collection du Cirp, 1, 63-78.

Groenewald, T. (2004). A phenomenological research design illustrated. International Journal of Qualitative Methods, 3(1), 42-55.

Haahr, J. H., Nielsen, T. K., Hansen, M. E., \& Jakobsen, S. T. (2005). Explaining student performance: Evidence from the international PISA, TIMSS and PIRLS surveys. Taastrup, Denmark: Danish Technological Institute.

Laverty, S. M. (2003). Hermeneutic phenomenology and phenomenology: A comparison of historical and methodical considerations. International Journal of Qualitative Methods, 2(3), 21-35.

Hotulainen, R., Mononen, R., \& Aunio, P. (2016). Thinking skills intervention for lowachieving first graders. European Journal of Special Needs Education, 31(3), 360-375.

Iji, C. O., Abah, J.A., \& Anyor, J.W. (2017). Impact of cloud services on students' attitude towards mathematics education in public universities in Benue State, Nigeria. International Journal of Research in Education and Science (IJRES), 3(1), 228-244.

Iji, C. O., Abah, J. A., \& Anyor, J. W. (2018). Educational Cloud Services and the Mathematics Confidence, Affective Engagement, and Behavioral Engagement of Mathematics Education Students in Public Universities in Benue State, Nigeria. International Journal of Teaching and Learning in Higher Education, 30(1), 47-60.

Kilpatrick, J. (2008). The development of mathematics education as an academic field. A paper prepared for Plenary Lecture 1 at the Symposium on the occasion of the $100^{\text {th }}$ Anniversary of ICMI held in Rome, $5^{\text {th }}-8^{\text {th }}$ March, 2008 (pp 1-18).

Maqsud, M. (2006). Effects of metacognitive instruction on mathematics achievement and attitude towards mathematics of low achievers. Educational Research, 40(2), 237-433.

Marsh, J. (2014). 10 effective tips to teach math for slow learner. Retrieved on $20^{\text {th }}$ May, 2017 from http://edupln.ning.com/

Mayana, U. S. (2014). Impact of national teachers' institute training programmes on the capacity building of primary school teachers in Zamfara State (Unpublished Thesis). Zaria, Nigeria: Ahmadi Bello University (ABU) Zaria.

McPhail, J. C. (1995). Phenomenology as philosophy and method: Applications to ways of doing special education. Remedial and Special Education, 16(3), 159-165. 
Naakaa, T., Abah, J. A., \& Atondo, G. T. (2019). Influence of school environmental variables on students' performance in junior secondary school mathematics in Gwer-East Local Government Area of Benue State, Nigeria. International Journal of Research and Innovation in Social Science (IJRISS), 3(1), 61-70.

National Universities Commission - NUC. (2007). Benchmark minimum academic standards for undergraduate programmes: Education. Abuja: National Universities Commission.

National Universities Commission (2012). Approved/Accredited programmes of Nigerian universities. Abuja: National Universities Commission.

Odili, G. O. (2012). Towards a new paradigm of teaching mathematics in Nigerian universities: The role of mathematics educators. Online Journal of Science Teachers Association of Nigerian (STAN), 47(1).

Omotosho, O. J. (2013a). Assessment of students'performance: Grading systems. Information and Knowledge Management, 3(2), 26-50.

Omotosho, O. J. (2013b). Evaluation of grading systems of some tertiary institutions in Nigeria. Information and Knowledge Management, 3(2), 92-124.

Reiss, S. (2009). Six motivational reasons for low achievement. Child \& Youth Care Forum, 38(4), 219-225.

Scneider, S., \& Lee, Y. (1990). A model for academic success: The school and home environment of East Asian students. Anthropology \& Education Quarterly, 21(4), 358377.

Sriram, R. (2014). Rethinking intelligence: The role of mindset in promoting success for academically high-risk students. Journal of College Student Retention: Research Theory \& Practice, 15(4), 515-536.

Steinmayr, R., Meibner, A., Weidinger, A.F., \& Wirthwein, L. (2015). Academic achievement. $\begin{array}{llll}\text { Retrieved } & \text { on } & 10^{\text {th }} & \text { September, }\end{array}$ http://www.oxfordbibliographies.com/view/document/obo-9780199756810/obo9780199756810-0108.xml

Technical Education Quality Improvement Programme (TEQIP) Phase II. (2012). Guidance brief - Improving the academic performance of weak students through the equity action plan. $\quad$ Retrieved on $29^{\text {th }} \quad$ April, 2017 from http://www.npiu.nic.in/pdf/I\%20P\%20W\%20S.pdf

Tufford, L., \& Newman, P. (2010). Bracketing in qualitative research. Qualitative Social Work, 11(1), 80-96.

United Nations Education, Scientific and Cultural Organization - UNESCO. (2012). Challenges in basic mathematics education. Paris: UNESCO.

Vogell, H., \& Fresques, H. (2017). Hidden dropouts: How school make low achievers disappear. Retrieved on $20^{\text {th }} \quad$ May, 2017 from https://www.usatoday.com/story/news/2017/02/21/hidden-dropouts-how-schools-gamesystem-dumping-underachievers-into-alternative-programs/97708866/

Williams, E. (n.d.). What is the meaning of academic performance? Retrieved on $10^{\text {th }}$ September, 2016 from http://work.chron.com/meaning-academic-performance17332.html

Wilson, T. D., Damian, M., \& Shelton, N. (2002). Improving the academic performance of college students with brief attributional intervention, In J. Aronsn (Ed.), Improving Academic Achievement: Impact of Psychological Factors on Education (pp. 89-108). New York: Academic Press. 